\title{
THE DICHOTOMY OF THE LEGAL STATUS OF SEXUAL MINORITIES: A CRITICAL ANALYSIS OF JUDICIAL TRENDS ACROSS THE GLOBE AND INDIA
}

\section{Smiriti Brar and Sweenab Dutta}

\author{
Indian Law Institute, New Delhi, India. Email: smritibrar@gmail.com
}

National Law School of India University, Bangalore, India. Email: swarnabhdutta@nls.ac.in

\begin{abstract}
The ever-controversial issue of sexual minorities and homosexuality has remained contentious since the very term was introduced, primarily because it has been seen as unnatural and does not correspond with what society as well as the legal norms prevailing in the society, define as 'normal'. It becomes imperative to briefly examine the development of the laws governing these populations and their impact on the societies' evolving attitudes towards homosexual relationships and transgender, to show the progress of the gay liberation movement and its effects on formulation of the laws in the society. Aside from the judgment of the heterosexual world, many myths about homosexuality have been imagined. Thus, with this backdrop on the issue at hand, the authors aspire to analyze and attempt to unveil these myths, arguing about the welfare and protection of these classes of individuals who fight a daily battle to secure their identities in the society we dwell in. The authors strive to comprehend the legal status of the LGBT communities across the globe and compare their plight to that in India, to critically analyze their legal rights and interests and ensure the level of implementation in the various regimes, to comprehend the various judicial measures that have been undertaken to safeguard the very existence of such communities, and conclusively enunciate the various lessons that could be learnt from the ongoing judicial trend and how the same may be put in application considering the Indian modus operandi. The authors aim to dig deep into the concerns where these aversions in relation to homosexuality can be reversed and the society could evolve as broad-minded, understanding the concerns of such persons who live under the constant apprehension of being 'found out' and the various forms of discrimination and atrocities that they have faced and are still facing under the present Indian legal regime.
\end{abstract}

Keywords: sexual minorities; homosexuality; legal status; judicial trends; India

\section{Understanding the Plight of the Sexual Minorities - Who They Are And What Do They Deserve \\ Sexual relationships represent a fundamental element of individual identity and an intimate aspect of an individual's private life. Although there have always been and will always be a cluster of people who engage in homosexual relationships and activities, being 'gay' is a modern political concept that has emerged in response to the deprivation of rights on the basis of sexual orientation.}

Sexual minorities have made substantial progress in obtaining protections of their basic human rights in Australia, 
parts of Latin America, North America, South Africa and Western Europe, but discrimination on the basis of sexual orientation still persists throughout most of the developing world.

LGBT relations are criminalized in over approximately eighty-two nations, and the penalty for being gay often includes public humiliation, hard labor, confinement, torture, harassment, blackmail, spurious trials with no right to appeal or death. Very few of these laws, however, actually specify the type of conduct that is forbidden, and this lack of specificity allows States greater flexibility in implementing these laws.

It is significant to highlight that to assess the extent of rights violations against sexual minorities and of State and non-State responses in any year are a very difficult task given the paucity of reliable information in today's scenario. It is with this line of thought that the authors would now like to commence with the next aspect pertaining to the identification of these marginalized groups.

\section{Lifting the veil on 'Sexual Minorities'}

Sexual minorities are a group whose sexual identity, orientation or practices differ from the majority of the surrounding society. Usually, sexual minorities comprise of lesbian, gay, bisexual and transgender individuals. Male-female dichotomy in hetero-normative societies has created havoc in the life of sexual minorities, thus, obscuring the fact that they are also human beings. The intent of the authors here is to bring to light the violation of basic human rights of this community and need for provision of equal opportunities and protection of rights like any other law-abiding citizen.

The most common use of the term sexual minority includes people who are homosexual, including men who are sexually attracted to and/or have sex with men, and women with women; and women and men with both men and women. Sexual minorities also include 'transgender', that is men and women who identify themselves as the opposite gender, whether or not they have undergone any kind of gender re-assignment, and people with intersex characteristics, who are born with or develop anatomical sexual characteristics that are neither typically male nor typically female, or who have what appears to be a combination of male and female characteristics.

Adopted by consensus in 1992, the United Nations Minorities Declaration in its Article 1 refers to 'minorities' as based on 'national or ethnic, cultural, religious and linguistic identity, and provides that States should protect their existence'. There is no internationally agreed definition as to which groups constitute the 'sexual minorities'. It is often stressed that the existence of a minority is a question of fact and that any definition must include both objective factors such as the existence of a shared ethnicity, language or religion and subjective factors including that individuals must identify themselves as members of a minority.

\section{The gallant efforts to protect 'sexual minorities'}

The founding document on which most human rights organizations base their advocacy is the Universal Declaration on Human Rights. From this initial document has emerged a whole series of human rights declarations, conventions and treaties pertaining to the rights of various marginalized groups and communities. However, one significant absence in international human rights law has been an express articulation of the specific interests of sexuality minorities. This silence is dismaying.

But with the gradual passage of time and on a positive note, the year of 1991 marked a milestone in the recognition of this marginalized community. The Amnesty International for the first time came out with a policy to support the rights of people imprisoned because of their sexual orientation or because of engaging in homosexual activity in private. In the mid 1990's, the Human Rights Committee held that the anti sodomy law of Tasmania violated the right to privacy and the right to non discrimination guaranteed to all persons under the International Covenant on Civil and Political Rights. In Scandinavia, the provision of equal rights for sexuality minorities, including marriage rights, was an important break-through. The other major development has been the South African Constitution, which for the first time expressly prohibited discrimination on grounds of sexual orientation. 


\section{Present State of Affairs: What it is and What It Ought to Be}

Attacks on sexual minorities are among the fastest growing types of aggression in the world. The number of incidents that remain unreported due to fear of persecution is even larger. Sexual minorities have gained some legal protections of their rights within national and regional arenas. However, as evidenced by the many examples provided, international protections have lagged far behind. In light of the atrocities against LGBT individuals around the world, human rights activists and organizations must demand greater human rights protections for sexual minorities.

As the largest international body and a self-proclaimed proponent of human rights, the United Nations must take a more active role in compelling action against offending States. Continued documentation, investigation and news reporting are necessary to ensure that systematic LGBT persecution is exposed. Although States and international bodies may amend their laws, advocates must not become complacent; new legislation, which confers greater protections on LGBT individuals, does not necessarily translate into governments effectively enforcing these laws. The effectiveness of any law will ultimately depend on the willingness of judges and lawmakers to ensure that the rights of sexual minorities are preserved. Advocates must also be cautious that what appears to be progress doesn't mask pervasive discrimination.

\section{The legal scenario pertaining to the LGBT communities: a country specific analysis}

Violation against the queer communities is not merely a local phenomenon and therefore, in this section the authors feel it pertinent to throw some light on the human rights discourse that has taken place in the global strands. While, the authors are clear on the aspect that individuals in India are subject to a very specific form of oppression, yet it is not possible to understand and estimate the degree of violation and its resistance without having a look at the global roots.

\section{The global scale of oppression}

The LGBT communities have often been excluded from the grant of protection that is afforded to all the class of individuals within the society by the State. This is manifested by a look at the provisions of the Islamic Penal Code wherein under the aegis of Article 110, it has been provided that the punishment for sodomy is killing. Article 121 reads that punishment for rubbing of thighs and buttocks committed by two men without entry shall be a hundred lashes for each one of them. Article 129 states that punishment for lesbianism is a hundred lashes for each individual and Article 131 provides that if lesbianism is repeated thrice, then death sentence would be prescribed the fourth time. In Saudi Arabia, all homosexuals are subjected to death penalty.

In various parts of Latin America, governments have been implicated for the extra judicial killings or have been found to take a passive tactic towards prohibiting the violations and killings at the hand of the perpetrators. In Colombia, the right-wing death squads are assigned the task of killing those who are socially undesirable like the vagrants, petty criminals, street children and the homosexuals. In Peru, the members of the LGBT communities have been systematically murdered and most specifically the transgender, as a part of the "cleaning of the undesirables campaign' during the 1980s. In Brazil, unidentified groups have been responsible for the killings of approximately 1300 members of these marginalized communities since the mid 1980s.

\section{The other side of the coin}

Contrariwise, Denmark, being one of the first countries to recognize the rights of the LGBT communities, has an extensive and highest degree of liberty that is provided. The same-sex sexual activity had been legalized way back in 1933 and the age of consent for the same has been fixed at 15 since 1977. Also, same-sex activity was legalized on June 15, 2012, consequent to the Danish Parliament voting in favor of a gender-neutral marriage.

In 1991, a request was made to the UNs Sub-Commission on the Prevention of Discrimination and Protection of Minorities for the equal rights and level of protection to the sexual minorities. Then, subsequently in Toonen $v$. Australia (U.N. Doc. CCPR/C/50/D/488/1992, Opinion Apr. 4, 1994) the UNHRC held that the Tasmanian law that criminalized same-sex activity violated the international norms and soon in 2003, Brazil along with 26 other States 
introduced a Resolution for the grant of human rights protections to the sexual minorities worldwide.

One of the most recent largest surveys conducted online by the European Union Agency for Fundamental Rights (hereinafter as FRA) observed and concluded that for the simple reason of hate crimes and discrimination, the LGBT people cannot be themselves in their daily lives.

Similarly, under the jurisdiction of the United States of America, sexual activity between adults who have given their free consent and adolescents of a close age, having the same sex had been legalized in 2003 after the landmark decision in Lawrence v. Texas (02-102) 539 U.S. 558 (2003), 41 S. W. 3d 349). At present, there are a total of 21 States that outlaw discrimination based on sexual orientation and gender identity or expression.

It is with this backdrop that the authors would now like to focus the lens on the Indian inhibitions surrounding homosexuality, highlighting the presence of innate homophobia.

\section{The Protections in India: The Dark Reality}

The Constitution of India under the ambit of Article 15 provides that 'there shall be no discrimination on the basis of the sex of the person', which is guaranteed to every individual as a fundamental right. The major concern that seeks a response is the understanding as well as the interpretation of the term 'sex', which has been referred only in the context of biological sex of the individual as male or female.

When we narrow down our focus to the Indian setup, the everlasting subsistence of Section 377, Indian Penal Code, has instilled a sense of hatred and dislike to such an extreme extent in the minds of the society that even the most learned of them all, the judges, are apprehensive of taking a bold step in recognizing the inadequacy of the ancient British product and till date, India struggles to legitimize homosexuality and the rights of other sexual minorities.

At this juncture, it is relevant to unravel the various intricacies of the draconian Section 377, which criminalizes unnatural offences and encompasses voluntary carnal intercourse against the order of nature with any man, woman or animal. As a piece of legislation, section 377 applies a vague offence, without defining what 'carnal intercourse' or 'order of nature' are, to the general public at large, the only criteria being 'penetration'. Secondly, it applies to both heterosexuals and homosexuals. Over the years, the general offence of sodomy became a specific offence of homosexual sodomy, a significant distinction although never reflected in the Indian law has subsequently been read through in certain later cases by the Indian courts.

With these legal provisions in place, there have occurred several instances of misuse and abuse that have undermined the dignity of the sexual minorities in India. In 2001, the Lucknow police received information that gay men were cruising in a public park and as a consequence, arrests and investigations were conducted under the garb of Section 377 and within a short span of two months, vigorous and spirited protests against the police and the magistrate took place and subsequently, the charges under Section 377 were dropped. Yet again in the year 2006, police arrested four men for allegedly having sex in a public park, as a clear violation of Section 377. Independent investigators observed that the entire case that was built up by the police was on the mere fact that those men were gay and thus should be punished under the provisions of the Indian Penal Code.

These incidents clearly stipulated that the mere existence of Section 377, in a certain way, added a sense of criminality to the lives of the homosexuals. They had to live under constant fear of being found out and that of moral terrorism. Thus, many have argued in favor of the benefits of decriminalization, which would tantamount not only to the augmenting the dignity of the homosexuals, but also would permit them to live their private lives peacefully as the most basic qualification for the grant of human rights.

\section{The Judicial Trends Outside and Within India: Interpretation For and Against the Sexual Minorities}

In the last two decades of the $20^{\text {th }}$ century, the entire world has been witness to the emergence of a new form of 
political assertion centering the private realm of sexuality. The traditional definitions governing the society have been forced to collide with the novel concerns of the LGBTs and specially, the extreme social intolerance, which has had immense psychological impact on the lives of such individuals belonging to the marginalized communities. In this segment, the authors strive to ascertain the predominant role of the judicial wing in establishing the bases for the recognition of the rights of the LGBTs throughout the world and in India.

\section{Before the Human Rights Committee under International Covenant on Civil and Political Rights (ICCPR)}

The decision by the UNHRC in the case of Toonen v. Australia (U.N. Doc. CCPR/C/50/D/488/1992, Opinion Apr. 4, 1994), was a milestone in the development of human rights accorded to the LGBTs under the prevailing international law as illustrated under the ICCPR. In its decision, the HRC was of the opinion that adult consensual sexual conduct in private is covered and protected by the right to privacy and that Toonen was a victim under the continued existence of the Tasmanian laws, which interfered with his right to seek privacy, despite the lack of recent enforcement of the impugned provisions.

\section{Before the European Court of Human Rights}

In the remarkable decision of Dudgeon v. The United Kingdom (45 Eur. Ct. H.R. (ser A.) (1981), the matter pertained to a legislation, which was then in force in the Northern Ireland and categorized same-sex activities between males as a crime under the law. This case proved to be a landmark decision delivered by the Court, as it was the first of its kind. Thus, this case was the first one, which expressly stated that the homosexuals were to be accorded the same level of protection by the State as any other individual. This case was only the $35^{\text {th }}$ case that was decided by the ECtHR and as a major consequence of this judgment, homosexual relations between men were decriminalized and what was to be noted is that nowhere in the entire United Kingdom was homosexual sex between females a crime.

\section{In the United States of America}

The homosexual activities between consenting individuals of the United States had been validated after the landmark ruling in the case of Lawrence v. Texas (02-102) 539 U.S. 558 (2003), 41 S. W. 3d 349). The SC agreed to hear the case in 2002 and the representatives coordinated the submission of 16 amicus curiae briefs along with their submissions. During the proceedings, the States of Alabama, Utah, and South Carolina provided the Court with the Reports stating that homosexual sodomy had adverse and severe emotional, physical, spiritual and psychological consequences. In 2003, the Court released its 6:3 decision holding that the Texas law was unconstitutional and needed to be struck down as it violated procedural as well as equal protection guarantees.

\section{The Indian jurisdiction}

In the landmark decision of Naz v. NCT Govt. of Delhi (2010 Cri LJ 94, 160 (2009) DLT 277, 160 (2009) DLT 277 (para 1, Judgment), a writ petition was preferred by Naz Foundation, a Non Governmental Organization (NGO) as a Public Interest Litigation to challenge the constitutional validity of Section 377 (The Indian Penal Code, Act No. 45 of 1860). The challenge was found on the plea that Section 377, on account of it covering sexual acts between consenting adults in private infringes the fundamental rights guaranteed under the Constitution of India. The Court was of the opinion that the impugned provision in Section 377 criminalized the acts of sexual minorities particularly MSMs. It disproportionately impacted them solely on the basis of their sexual orientation. The provision ran counter to the constitutional values and the notion of human dignity, which is considered to be the cornerstone of our Constitution. A provision of law branding one section of people as criminal based wholly on the State's moral disapproval of that class goes counter to the equality guaranteed under the Constitution under any standard of review. The Court declared that Section 377, insofar it criminalized consensual sexual acts of adults in private, was violative of the Constitution.

After a span of 4 years, the nation witnessed a significant deviation from the earlier decision, based on the argument that the matter decided by the High Court was not within its purview and that the decision required a rebuttal as it had an adverse impact on the religious concerns of the citizens of India. In Suresh Kumar Koushal and Ors. v. Naz 
Foundation and Ors (Civil Appeal NO.10972 OF 2013 (Arising out of SLP (C) No.15436 of 2009), decided on December 11, 2013 the Court stated that the judiciary had to exercise 'self-restraint' while dealing with challenges to the constitutionality of the laws. Going on to the extreme mode of confining itself, the Court observed that the mere fact that the provision was misused by the police and other authorities, did not reflect the vires of the impugned Section. And as an icing on the cake, the Court clarified that it had merely pronounced on the correctness of the view taken by the High Court and not framed its opinion on the issue. Heavy criticism followed this controversial decision. Critics across the nation, from all walks of legal profession, vehemently and unanimously voiced their discontentment with the decision opining that the Court disproportionately devoted its focus on the critique of the earlier decision by the High Court and that the Court deserted its own duty to determine the finality of the constitutionality of the impugned provision. It was lamented that the supremely supreme Apex Court of the Indian legal system says, '...go to the Parliament...' It was observed by many that the Indian Constitution asserts a commitment to equality and justice for all but relegates its own nationals to second-class citizenship on account of their sexual orientation, and in doing so, it contravenes international law and the dictum of respected HR instruments.

The year 2014 witnessed a respite and paved the way for recognition of transgender persons as a third gender. In National Legal Services Authority v. Union of India (WP (Civil) No 604 of 2013), the Court responded to the plight of the Transgender Community ('TC' hereinafter), the constant abuses and public ridicules and the fact that India had witnessed a moral failure as the unwillingness of the society to acknowledge the presence of various gender identities and expressions. The Hon'ble SC referred to a plethora of international and regional decisions and also a section was completely devoted to the various legislations that enabled the recognition of the rights of the members of the TC. The Court opined that there was an absence of a suitable legislation that led to the growth in the discrimination and rejection of the TC in the society. Thus, on the basis of the above discussion, the Court observed that the provisions under Constitution, under no circumstances excluded the TC from their operation and that the non-recognition that has taken place since decades has led to the denial of equal protection of law and equality before the law for such individuals facing gross violations in lieu of their physical and mental well being. On a concluding note, the Court held that the use of the expressions 'person', 'citizen' and 'sex' are gender neutral expressions and cannot be restrictively interpreted to not include TCs.

\section{Conclusion}

Over the stretch of time, the authors concede to the fact that there has been a plethora of evidence to showcase that the sexual minorities have gained a certain degree of legal protection at the international level, but one cannot ignore that such protections have lingered far behind the expectations of the LGBTs. And what cannot be overlooked is that without a stronger position at the international platform and a strengthened stance taken by the international human rights institutions, the entire revolt of these marginalized communities would have no guiding and unifying element attached to it. The authors would like to state that in the present scenario, the litigation concerning sexual minorities, possesses the potential of defusing the power of the gender/orientation as a mechanism for discrimination, and that the jurisprudential reliance on the 'biological sex' as the sole indicator of gender identity leads to arbitrariness and is henceforth worth contesting.

It cannot be ignored that these suppressed class of individuals face a variety of legally sanctioned and State or societal form of covert discriminations. It must be noted that the current concerns regarding the struggles of the homosexuals and the similar has been a consequence of the relentless agitation and activism by the LGBTs across the globe, who had to face obstruction at every step of their long battles under the cloud of 'criminality' against the State as well as the intransigent society for the grant of what is fundamental to the very survival of these individuals.

To conclude this piece of research work, the authors would like to emphasize that abnormality in this heterosexual world will continue to be judged where common misconceptions persist. It must be better understood that sexuality is nothing more than a human condition and therefore must not be regarded as a depravity, crime or a sin. 


\section{Bibliografi}

1. Amnesty, Int'l, OUT front! Lesbian, Gay, Bisexual and Transgender Human Rights, http://www.amnestyusa.org/Our_Iss-ues/LGBT_Human__Rights/page.do?id=1011002\&n1=3\&n2=36 (last visited Aug. 10, 2006).

2. Bailey, D.S., (1955) 86 Homosexuality and the Western Christian Tradition (London: Longman)

3. Barnard, Ian, (2004) Queer Race: Cultural Interventions in the Racial Politics of Queer Theory 108.

4. Blasius, Mark, (2001) Sexual Identities, Queer Politics 217.

5. Carroll, Aengus, (2010) Make It Work: Six steps to effective LGBT human rights advocacy, The European Region of the International Lesbian, Gay, Bisexual, Trans \& Intersex Association (ILGA) http://www.eidhr.eu/files/dm-file/advocacy manual ww-w1.pdf.

6. Carter, David, (2010) 69 Stonewall: The Riots that Sparked the Gay Revolution.

7. Cory, D.W., (1951) 27 The Homosexual in America: A Subjective Approach.

8. Eaklor, Vicki Lynn, (2008) Queer America: A GLBT History Of The $20^{\text {th }}$ Century, 92.

9. Goodman, Ryan, (2001) Beyond the Enforcement Principle: Sodomy Laws, Social norms, and Social Panoptics, California Law Review 89 (3): 643-740.

10. Gupta. Alok, (2006) Section 377 and the Dignity of Indian Homosexuals, Economic and Political Weekly 4818, November 18.

11. Heinze, Eric, (1995) Sexual Orientation: A Human Right 37 (Kluwer Academic Publishers 1995).

12. Holning, Lau, (2004) Sexual Orientation: Testing the Universality of International Human Rights Law, 71 U. CHI. L. REV. 1689, 1704.

13. Human Rights Watch, World Report (2012-13), ISBN-13: 978-1-60980-389-6, 24 https://www.hrw.org/sites/default/files/wr2013 web.pdf.

14. Int'l Gay \& Lesbian Human Rights Comm'n, Resolution on Sexual Orientation and Human Rights, http://www.iglhrc.org/files/iglhrc/pro-gram_docs/actionkit-final\%5B1-\%5D.doc.pdf (last visited Mar. 3, 2006).

15. Int'l Lesbian \& Gay Ass'n, Legal Survey on the Countries in the World having Legal Prohibitions on Sexual Activities between Consenting Adults in Private (2005-06), Http://Www.llga.Org/Statehomopho-Bia/Lgbcriminallawsdaniel Otto-Son.Pdf.

16. Manon Tremblay, Carol Johnson, David Paternotte, 121 The Lesbian and Gay Movement and the State: Comparative Insights into a Transformed Relationship (Ashgate Publishing)(2011).

17. Mark Blasius, 217 Sexual Identities, Queer Politics (2001).

18. Miller, A., Sexual Rights: Conceptual Advances and Tensions in Debate, Sexual, Reproductive and 
Human Rights Seminar, Lima, Peru, November 2001. p. 1, available at http://www.choike.org/documentos/alice_miller.pdf (Last visited on July 5, 2013).

19. Nordberg, Erica, (2012) Ignoring Human Rights for Homosexuals: Gross Violations of International Obligations in Cameroon, American University International Law Review Volume 27 Issue 2: 439-472

20. Olsen, Birgitte Kofod, (2008) Legal Study on Homophobia and Discrimination on Grounds of Sexual Orientation - Denmark.

21. Redding, Jeffrey A., (2006) Human Rights and Homo-Sectuals: The International Politics of Sexuality, Religion, and Law, 4 NW. J. INT'L HUM. RTS. 436, 437.

22. Roberts, Steven V. 'Gay' People Demand their Rights, N.Y. TIMES, Jul. 5, 1970 at 100, Homosexuals in Revolt, N.Y. TIMES, Aug. 24, 1970 at 1.

23. Ruse, Austin, (2012) Human Rights, Sexual Orientation, and Gender Identity at the UN, The Witherspoon Institute http://www.thepublicdiscourse.com/2012/1-1/7213/.

24. Stewart, Chuck, (1951) Gay and Lesbian Issues 1 (Abc-Clio, Inc. 2003).

25. The United Nations Human Rights Treaties, Equality and Discrimination: Sexual Orientation Concluding http://www.bayefsky.com/themes/equalitysexual concludingobservations.php.

Observations,

26. UN Commission on Human Rights, Work of the Sub-Commission on Prevention of Discrimination and Protection of Minorities, 7 March 1990, E/CN.4/RES/1990-64, available at: http://www.refworld.org/do-ci-d/3b00f0ac1-c.html.

27. UN Secretary-General Ban Ki-Moon and UN High Commissioner for Human Rights Navi Pillay, Speeches and Statements by UN Officials: References to Sexual Orientation and Gender Identity, Report of the UN High Commissioner on Human Rights on Discriminatory laws and practices and acts of violence against individuals based on their sexual orientation and gender identity (2011) https://iglhrc.org/sites/de-fault/files/UN-\%200fficials RefSOGI.pdf.

28. US Department of State, Country Reports on Human Rights Practices for 2012, available at http://www.state.gov/i/drl/rls/hrrpt/human-rights-report/index.htm\#wrapper.

29. Vantia, Ruth, (Ed.)(2002) Queering India: Same-Sex Love And Eroticism In Indian Culture And Society, Routledge, p 17.

30. The Botswana Network on Ethics, Law and HIV/AIDS, (2008) The Lesbians, Gays and Bisexuals of Botswana, Global Rights International Gay and Lesbian Human Rights Commission, The Violations of the Rights of Lesbian, Gay, Bisexual and Transgender Persons in Botswana: A Shadow Report-2008, http://www.asylum-law.org/do cs/sex ual-mino-rities/BOTSWANA033108.pdf.

31. The McCreary Centre Society, (2007) Not Yet Equal: The Health of Lesbian, Gay, \& Bisexual Youth in $B C$, ISBN: 978-1-895438-84-5.

32. Torture 'Widespread' In Uganda, 2004 BBC News International Version, , 
http://news.bbc.co.uk/2/hi/africa/37563-54-.stm.

33. Math, Suresh Bada and Seshadri, Shekhar P., (2013) The invisible ones: Sexual minorities, 4 Indian J. Med. Res. 137, pp 4-6. 